\title{
Exploring the Multicultural Competence of Leadership Educators
}

\author{
Amy B. Wilson, Ph.D. \\ Assistant Professor \\ Higher Education Administration Department \\ Buffalo State College \\ 312F Bacon Hall \\ 1300 Elmwood Avenue \\ Buffalo, NY 14222 \\ wilsonab@buffalostate.edu \\ 716-878-4083
}

\begin{abstract}
Research examining multicultural competence among higher education professionals responsible for leadership education demonstrated significant correlations with racial identity and multicultural education and experiences. The Multicultural Competence in Student Affairs-Preliminary 2 (MCSA-P2) scale was used to measure multicultural competence. Variances in multicultural competence scores were significant in relation to racial identity and select multicultural education and experience measures, above and beyond controlled for demographic variables.
\end{abstract}

\section{Introduction}

Although leadership development has long been a central goal for most colleges and universities, evidence suggests a renewed commitment to co-curricular programs that focus on civic responsibility and social change (Astin \& Astin, 2000; Council for the Advancement of Higher Education, 2006; Dugan, Komives, \& Segar, 2008; HERI, 1996). Specifically, the number of co-curricular programs focused on leadership and social change has more than doubled in the past two decades (Scott, 2004). Scholarly research on the developmental outcomes of students involved in leadership on campus has also increased, particularly through the Multi-Institutional Study of Leadership [MSL] (Dugan \& Komives, 2007). The first iteration of the MSL (2007) produced several significant findings related to diversity and leadership. Important to this study was evidence that the single-strongest environmental predictor of leadership outcomes was the opportunity for students to engage in conversations across differences (Dugan \& Komives, 2007). This has potentially significant implications for the field of leadership education and in particular, the student affairs staff responsible for developing student leadership experiences.

The ability and knowledge to facilitate cross-cultural conversations and respond to multicultural issues is often deferred to those perceived as the diversity experts on campus, who have a more vested interest in the subject and may have had advanced training or education in the area (Pope, Reynolds, \& Mueller, 2004). However, Pope and Reynolds (1997) offer a conceptual model of multicultural competence, which unlike other sets of identified competencies urges student affairs to adopt multicultural competence as a core competency for all professionals in the field rather than a few designated experts. Given the MSL evidence and support for creating opportunities for students to engage in cross-cultural conversations (Dugan \& Komives, 2007), it may be particularly relevant to consider the multicultural competence of those professionals responsible for developing these opportunities and facilitating these conversations. 
While several previous studies have examined multicultural competence among student affairs professionals (Miklitsch, 2005; Muller \& Pope, 2001; Weigand, 2005), very little research has focused on the role of the leadership educator. More specifically, no research has examined the capacity of leadership educators to fulfill the changing and increasingly diverse nature of leadership education. Therefore, this study explores the multicultural competence of student affairs professionals responsible for leadership education as it relates to the growing demonstrable need in the profession.

\section{Leadership Education and the Leadership Educator}

Co-curricular leadership education continues to evolve in much the same way as the term leadership itself has evolved, shifting from an industrial perspective to a more relational, reciprocal model (Burns, 1978; Komives, Lucas, \& McMahon, 2007; Northouse, 2007; Rost, 1991). Most campus leadership programs have taken a transformational approach, recognizing that leadership is a process not a position and promote the values of higher education in preparing a new generation of leaders to tackle the social, economic, political and educational problems facing society (Colby, Ehrlich, Beaumont, \& Stephens, 2003; HERI, 1996; Jacoby \& Associates, 1996).

Along with these changes has come the professionalization of the leadership educator role, recognizing the importance of the role and the need to support student affairs educators working directly with students in the area of leadership development (Komives, Dugan, Owen, Slack \& Wagner, 2006). Organizations such as the National Clearinghouse for Leadership Programs (NCLP), Association of Leadership Educators, as well as targeted conferences and journals offer opportunities to engage in discussion about leadership development practices (Dugan \& Komives, 2007). Competencies for leadership educators have been identified to include knowledge of student learning and development theory, cross-cultural competence, and attentiveness to unique student populations among others (Wagner, 2006). In addition, books and resources specifically targeting college student leadership have emerged, validating the important role of leadership education (CAS, 2006; Northouse, 2007) and the role of the leadership educator.

\section{Multicultural Competence in Student Affairs}

Previous research demonstrated that student affairs practitioners are underprepared to work in multicultural environments, as their graduate preparatory experiences have provided limited information on multiculturalism (Flowers, 2003; McEwen \& Roper, 1994; Pope \& Mueller, 2005; Talbot, 1992). Given this inadequacy, Pope and Reynolds (1997) identified multicultural competence as a necessary prerequisite for effective and ethical student affairs practice expanding beyond graduate coursework. They proposed a tripartite definition and model consisting of multicultural awareness, knowledge, and skills. The Dynamic Model of Student Affairs Competence (Pope \& Reynolds, 1997; Pope, Mueller, \& Reynolds, 2004) builds upon other core competencies and standards of good practice such as administrative, management and leadership skills; ethical and legal knowledge and decision making skills; student development theory and translation; individual and group helping and interpersonal skills; and, assessment, evaluation and research skills (ACPA, 1996; ACPA, 2010; Barr, Desler \& Associates, 2000; Miller, 2003; Pope \& Reynolds, 1997). However, unlike other models, the Dynamic Model of Student Affairs Competence suggests that multiculturalism should be infused and integrated into each of 
the core competence areas such that effective management and leadership would include the encouragement of diverse perspectives and diverse approaches to supervision.

Earlier studies on the multicultural competence of student affairs professionals have suggested that racial identity, select demographic variables (i.e., gender, sexual orientation, degree level), and multicultural educational and experiential opportunities (i.e., supervision, diversity workshops, course work, increased cross cultural exposure) may also be related to multicultural competence (King \& Howard-Hamilton, 2003; Miklitsch, 2005; Mueller \& Pope, 2001; Weigand, 2005). These variables will be further defined and explored below in relation to how they may impact the multicultural competence of professionals in the field.

\section{Racial Identity}

Previous research on multicultural competence has demonstrated a positive relationship between racial identity and one's level of multicultural competence (King \& Howard-Hamilton, 2000; Miklitsch 2005; Mueller \& Pope, 2001; Weigand 2005). Racial identity is defined by Helms (1990a) as "a sense of group or collective identity based on one's perception that he or she shares a common racial heritage with a particular racial group" (p. 3). In addition to acknowledgement of shared membership in a racial group, racial identity also refers to the quality or manner of one's identification with that group.

Although several models of racial identity development have been constructed, the People of Color and White racial identity development models proposed by Helms (1984; 1990a; 1990d; 1995a; 1995b; 1996; Helms \& Carter, 2002) were selected for this study. The People of Color Racial Identity development theory proposed by Helms is an enhancement of her theory of Black racial identity development and is meant to be inclusive of all people who are racially marginalized. Helms based her statuses on Cross' (1971) model of psychological Nigresence, which is explained as a transformation from a pre-existing identity based on a re-socializing experience (Helms, 1990a). From these social interactions and experiences, Helms proposed that one might move from one stage of racial identity development, with little or no racial awareness to another more complex stage of greater racial consciousness and salience.

The White racial identity development model, in much the same way as Helms' People of Color model, provides a framework for understanding identity formation of White people and their relationship with people of color and other White people. The essence of the model proposes that White individuals progress through a series of identity ego statuses representing developmental maturation and sophistication, from an abandonment of racism to a non-racist White identity (Evans, Forney, \& GuidoDiBrito, 1998; Helms, 1990c).

\section{Multicultural Education and Experience}

Multicultural education and experience interest variables include education and training around multicultural issues, developing and implementing multicultural programs and policies, discussing multicultural issues with supervisors, and interest in working with diverse students and colleagues (King \& Howard-Hamilton, 2001; Mueller \& Pope, 2001, 2003). Previous research examining the relationship between these variables and multicultural competence in student affairs populations has demonstrated significant correlation (Miklitsch 2005; Mueller \& Pope 2001; Weigand, 2005), providing a strong 
argument for comprehensive multicultural education and training within graduate preparation programs and beyond, as well as continued exposure and engagement in multicultural discussions (Pope \& Reynolds, 1997; Talbot, 1992).

While literature has suggested that graduate preparation and training programs do not adequately provide the necessary multicultural knowledge, awareness and skills, research has not fully explored how one might develop multicultural competence or what experience or factors may enhance one's level of multicultural competence. Further research is warranted understand the nature of the relationship between racial identity and its positive influence on multicultural competence, as well as the impact of other continued education and experience. Additionally, as previously mentioned, current research within the area of leadership education and development has indicated that the opportunity for students to engage in socio-cultural conversations is the single-strongest environmental predictor of leadership outcomes; however, there has been no research to date on the role of the leadership educator and whether they possess the knowledge or ability to properly facilitate these conversations or learning experiences. In fact, there is very little research on leadership educators as a whole. In response, this study examined multicultural competence among student affairs professionals responsible for leadership education by addressing the following two questions:

- What is the relationship between racial identity and multicultural competence?

- What is the relationship between multicultural education and experiences and multicultural competence?

\section{Method}

\section{Population}

Participants for this study were student affairs professionals who self-identified as being responsible for some portion of leadership education at colleges and universities throughout the United States. The sample included full-time student affairs professionals, who earned at least a bachelor's degree, including entry level staff (e.g., program assistants, coordinators, or assistant directors) as well as mid-level to senior-level administrators (e.g., associate directors, directors, assistant deans, or deans). Graduate students in a student affairs preparation program who held a graduate assistantship or internship in leadership education were also included, as well as some self-identified faculty in higher education.

\section{Sample}

A total of 307 professionals began the survey, however 140 (45.6\%) did not fully complete the survey, which consisted of three self-reporting instruments. It is believed that the length of the instruments may have caused some participants to opt out of full participation. Therefore, the total sample for the study was $167(N=167,54.5 \%)$. Descriptive statistics for the sample based on demographics are presented in Table 1. 
Table 1

Descriptive statistics for sample based on demographics

\begin{tabular}{|c|c|c|c|}
\hline Variable & & Frequency $n$ & $\%$ of sample \\
\hline \multirow[t]{2}{*}{ Gender } & Male & 52 & 31.5 \\
\hline & Female & 112 & 67.9 \\
\hline \multirow[t]{6}{*}{ Race/Ethnicity } & African American/Black & 17 & 10.2 \\
\hline & Asian American/Pacific Islander & 8 & 4.8 \\
\hline & Caucasian/White & 126 & 75.4 \\
\hline & Latino(a)/Chicano(a)/Hispanic & 13 & 7.8 \\
\hline & Native American/Alaskan Native & 1 & .6 \\
\hline & Multiracial & 2 & 1.2 \\
\hline \multirow[t]{4}{*}{ Highest degree earned } & Bachelors & 11 & 6.6 \\
\hline & Masters & 132 & 79.0 \\
\hline & Doctorate & 15 & 7.6 \\
\hline & Other & 1 & .6 \\
\hline \multirow{9}{*}{$\begin{array}{l}\text { Years as a full-time } \\
\text { professional }\end{array}$} & Less than 1 year & 7 & 4.3 \\
\hline & 1 year & 8 & 4.9 \\
\hline & $2-3$ years & 19 & 11.7 \\
\hline & $4-5$ years & 27 & 16.6 \\
\hline & $6-10$ years & 48 & 29.4 \\
\hline & $11-15$ years & 23 & 14.1 \\
\hline & $16-20$ years & 13 & 8.0 \\
\hline & $21-25$ years & 12 & 7.4 \\
\hline & $25+$ years & 6 & 3.7 \\
\hline \multirow[t]{6}{*}{ Current position level } & Graduate student & 9 & 5.4 \\
\hline & Entry level & 35 & 21.0 \\
\hline & Mid level & 90 & 53.9 \\
\hline & Senior level & 26 & 15.6 \\
\hline & Senior student affairs officer & 6 & 3.6 \\
\hline & Other & 1 & .6 \\
\hline \multirow{5}{*}{$\begin{array}{l}\text { Time spent on leadership } \\
\text { programming }\end{array}$} & $0 \%$ & 6 & 3.6 \\
\hline & $25 \%$ & 87 & 52.1 \\
\hline & $50 \%$ & 32 & 19.2 \\
\hline & $75 \%$ & 31 & 18.6 \\
\hline & $100 \%$ & 11 & 6.6 \\
\hline
\end{tabular}

$\mathrm{N}=167$ 
Institutional type was overrepresented by 4-year institutions, with nearly all (96.4\%) participants indicating employment at a 4-year college or university. However, the sample was nearly equally divided with regards to public (48.5\%) and private (47.9\%) institutions. Almost a third $(28.7 \%)$ reported working at an institution with an enrollment of 20,000 students or more, while $51.5 \%$ reported an enrollment of 10,000 students or less.

Additional descriptive data includes participant's identification with a socially marginalized group. This aspect was explored based on previous research conducted on multicultural competence suggesting that membership in a socially marginalized group was related to multicultural competence (Mueller, 1999; Mueller \& Pope, 2001; Ottavi, Pope-Davis, Dings, 1994; Pope \& Mueller, 2005, Weigand, 2005; Miklitsch, 2005). A large proportion (77.1\%) reported being a member of one or more socially marginalized groups, with $56.9 \%$ reporting membership as a woman, $22.2 \%$ as a person of color, $18 \%$ as gay/lesbian/bisexual, $9.0 \%$ as a religious minority, and $2.4 \%$ identifying as an individual with a disability.

\section{Data Collection}

Participants were solicited via email through two national listservs affiliated with professional organizations whose focus is leadership education and provide support for leadership educators. A snowball sampling technique was also used to increase participant response which asked participants to either fill out the survey themselves and/or forward the invitation to campus colleagues who may also identify as a leadership educator or who are responsible for some aspect of leadership education on their campus. This technique was used to capture responses from those who may not be members of the aforementioned listservs.

\section{Instrumentation}

Data collection for this study included four self-reporting instruments. All participants were asked to complete the Personal Data Form [PDF] (adapted from Pope, Miklitsch, \& Weigand, 2004), which was designed to identify the demographic factors mentioned above that may influence multicultural competence and racial identity in addition to information about participants multicultural education and experience. The second instrument that all participants completed was the Multicultural Competence in Student Affairs-Preliminary 2 scale [MCSA-P2] (Pope \& Mueller, 2000). The MCSA-P2 is a 34-item questionnaire, which asks participants to indicate how accurately each statement describes their beliefs when working in a student affairs setting. Participants use a 7-point Likert-type scale, ranging from 1 (not at all) to 7 (very accurate) to describe their beliefs. The MCSA-P2 was designed based on the tripartite model of multicultural awareness, knowledge, and skill, but produces an overall score for multicultural competence. The MCSA-P2 has continued to demonstrate a satisfactory level of internal consistency with an alpha coefficient of 90 or higher (King \& Howard-Hamilton, 2003; Miklitsch, 2005; Muller \& Pope, 2001; Pope \& Mueller, 2000; Weigand, 2005).

In order to measure and quantify racial identity, participants who identified as White were asked to complete the White Racial Identity Attitude Scale [WRIAS] (Helms \& Carter, 1990) and participants who identified as a person of color were asked to complete the People of Color Racial Identity Attitude Scale [POCRIAS] (Helms, 1995b). The WRIAS was developed based on Helms' (1984) model of White Racial Identity Development and measures behaviors and attitudes about being White, other Whites, the White 
culture, and how these attitudes affect the person's racial identity development (Helms \& Carter, 1990). Similarly, the POCRIAS was designed to measure the information-processing strategies that are proposed to result from the shared racial socialization experiences of People of Color (Helms, 1995b). Specifically, the instrument measures the five racial identity statuses proposed by Helms (1990d; 1995a):

- Conformity/Pre-encounter.

- Dissonance.

- Immersion/Resistance.

- Internalization.

- Integrative Awareness.

Each of these instruments produce multiple sub scores for the various phases of development; however, for purposes of this study, the subscales were grouped into two phases of racial identity development for both the WRIAS and POCRIAS to allow for an examination of racial identity development for people of color and Whites using comparable measures. This was to done to also allow for comparison of data with prior studies looking at multicultural competence and racial identity (Miklitsch, 2005; Weigand, 2005).

\section{Data Analysis}

This study utilized an ex-post facto correlational research design to determine a relationship between multicultural competence, racial identity, and multicultural education and experiences of student affairs professionals. As part of the analysis, some variables were collapsed into two distinct categories. Specifically the category of race, which was collapsed into Whites and people of color, based on the small sample size of people of color and the instruments chosen for measurement of racial identity. An initial analysis of the relationship of demographic variables to multicultural competence was conducted in order to determine which variables should be controlled for in regression analysis.

In order to determine racial identity development scores, participants' scores on the first three subscales of the WRIAS (contact, disintegration, and reintegration) were pooled to derive a Phase I score (Abandonment of Racism). Similarly, scores on the remaining three subscales (pseudo-independence, immersion/emersion, and autonomy) were combined to derive a Phase II score (Defining a Nonracist White Identity). To determine the racial identity development scores of those who identify as a Person of Color, scores on the first two subscales of the POCRIAS (conformity and dissonance) were combined for a Phase I score; subsequently, the final two subscale scores (immersion and internalization) were combined to derive a Phase II score. To examine the relationship between racial identity and multicultural competence a Pearson product-moment correlation was computed between each phase of racial identity and multicultural competence to determine whether a relationship was positive or negative and of statistical significance. A hierarchical multiple regression analysis was subsequently run to examine the extent to which a specific racial identity phase predicted levels of multicultural competence, above and beyond that which was accounted for by demographic variables.

To examine the relationship between multicultural education and experience variables and multicultural competence, correlation coefficients were computed initially for each variable. After determining significance, individual variables were lumped into one of two conceptual variables, multicultural 
education or multicultural experience. This collapsing of variables provided one score for each of the two conceptual independent variables, which were then entered into the hierarchical multiple regression model to analyze and predict variance in multicultural competence scores.

\section{Results}

An initial analysis demonstrated that race $(r=.298)$, membership in at least one socially marginalized group $(r=.341)$, and highest degree earned $(r=.187)$ all positively and significantly correlated with multicultural competence. These three variables were controlled for in the primary analyses in order to determine the extent to which the independent variables accounted for multicultural competence above and beyond the impact of race, membership in a socially marginalized group and highest degree earned. Gender and number of years as student a student affairs professional did not significantly correlate with multicultural competence in this study, but were included in the block of controlled variables used in the regression analysis because previous studies of multicultural competence have suggested a possible relationship between those variables and multicultural competence (Martin, 2005; Mastrodicasa, 2004; Pope \& Mueller, 2005). Table 2 presents the correlations between multicultural competence and the primary measures and subscales for this particular study, including the three significant demographic variables, racial identity measures, and multicultural education and experience scores.

Table 2

Pearson product-moment correlations between selected demographic variables and multicultural competence

\begin{tabular}{|c|c|c|c|c|c|c|c|c|}
\hline Variable & 1 & 2 & 3 & 4 & 5 & 6 & 7 & 8 \\
\hline $\begin{array}{l}\text { Multicultural } \\
\text { Competence }\end{array}$ & 1 & & & & & & & \\
\hline Race & $.30 * *$ & 1 & & & & & & \\
\hline $\begin{array}{l}\text { Socially } \\
\text { Marginalized }\end{array}$ & $.34 * *$ & $.28^{* *}$ & 1 & & & & & \\
\hline Highest Degree & $.19^{*}$ & .05 & .04 & 1 & & & & \\
\hline $\begin{array}{l}\text { Racial Identity } \\
\text { Phase I }\end{array}$ & $-.34^{* *}$ & -.08 & $-.21 * *$ & .01 & 1 & & & \\
\hline $\begin{array}{l}\text { Racial Identity } \\
\text { Phase II }\end{array}$ & $.58 * *$ & $.55^{* *}$ & $.27 * *$ & .06 & -.06 & 1 & & \\
\hline $\begin{array}{l}\text { Multicultural } \\
\text { Education }\end{array}$ & $.58 * *$ & $.23 * *$ & $.17^{*}$ & $.17^{*}$ & -.15 & $.40^{* *}$ & 1 & \\
\hline $\begin{array}{l}\text { Multicultural } \\
\text { Experience }\end{array}$ & $.62 * *$ & $.22 * *$ & .12 & .11 & -.16 & $.35^{* *}$ & $.66 * *$ & 1 \\
\hline
\end{tabular}

${ }^{*} p<.001, * * p<.05$ 
An analysis of the correlation between each racial identity phase and multicultural competence scores for both Whites and People of Color indicated that Phase I racial identity scores were negatively and significantly correlated with multicultural competence $(r=-.340)$ and Phase II racial identity scores were positively and significantly correlated with multicultural competence $(r=.580)$ for both groups. That is to say, participants with higher Phase I racial identity scores, which indicates a less mature phase of racial identity, subsequently had lower multicultural competence scores. Conversely, participants with higher Phase II racial identity scores, indicating a more mature phase of racial identity, subsequently had higher multicultural competence scores.

To further investigate and explain this relationship, a hierarchical multiple regression analysis was conducted, as shown in Table 3, to determine to what extent racial identity development explained variance in multicultural competence while controlling for the selected demographic variables. As a group, demographic variables accounted for significant variance in multicultural competence, $\mathrm{R}^{2}=.195$, $\mathrm{F}(6,153)=6.19, p<.001$. The six demographic variables accounted for a total of $19.5 \%$ of the variance in multicultural competence. The second step involved entering the variable block of racial identity into the regression, which accounted for significant additional variance in levels of multicultural competence above and beyond that accounted for by the demographics block, $\mathrm{R}_{\text {change }}^{2}=.297, \mathrm{~F}_{\text {change }}(2,151)=44.20, p$ $<.05$. This suggests that $29.7 \%$ of the variance in multicultural competence was accounted for by racial identity when controlling for the influence of demographics. This is lower than previous studies, which indicated 44.5\% variance (Weigand, 2005) and 41.0\% variance (Miklitsch, 2005).

Table 3

Summary of Hierarchical Regression Analysis for Demographic Variables and Racial Identity Explaining Variance in Multicultural Competence

\begin{tabular}{|lllll|}
\hline Predictor & $\mathrm{R}^{2}$ & $\mathrm{R}^{2}$ & $\mathrm{~F}_{\text {Change }}$ & $p$ \\
& & & \\
\hline $\begin{array}{l}\text { Change } \\
\text { Demographic Variable } \\
\quad \text { Gender }\end{array}$ & .195 & .195 & 6.188 & .000 \\
$\quad \begin{array}{l}\text { Race } \\
\text { Socially Marginalized Group }\end{array}$ & & & & \\
$\quad \begin{array}{l}\text { Highest Degree } \\
\text { Years in Student Affairs }\end{array}$ & & & & \\
\hline Racial Identity & .492 & .297 & 44.196 & .000 \\
$\quad$ WRIAS \& POCRIAS Phase I & & & & \\
$\quad$ WRIAS \& POCRIAS Phase II & & & & \\
\hline$p<.05$ & & & & \\
\end{tabular}


In sum, this hierarchical regression analysis implies that variance in multicultural competence among student affairs professionals responsible for co-curricular leadership education is significantly predicted by racial identity when statistically controlling for variance in demographic variables. In other words, there is a strong relationship between participants' racial identity and their level of multicultural competence regardless of demographic factors.

To measure which discrete multicultural education and multicultural experience variables were positively and significantly correlated to multicultural competence, a Pearson Product-Moment correlation matrix was constructed. Again, each of these measures was an aggregate of several items from the Personal Data Form (PDF). A regression analysis was then conducted to assess which variables predicted variance in multicultural competence.

All of the multicultural education variables were positively and significantly related to multicultural competence (see Table 4). That is to say, the more education that student affairs professionals working with leadership programs had that focused on multiculturalism and diversity, the higher their multicultural competence scores. Specifically, the number of graduate courses focused on diversity positively and significantly impacted multicultural competence $(r=.358, p<.01)$, suggesting that the more diversity courses one has taken, the greater their multicultural competence.

Table 4

Pearson Product-Moment Correlations between Multicultural Education Items and Multicultural Competence

\begin{tabular}{lc} 
Items & $r$ \\
\hline Graduate Courses Focused on Diversity & $.358^{* *}$ \\
\hline Diversity Workshops Attended in Past 2 Years & $.375^{* *}$ \\
\hline Diversity Articles, Books, Studies Read in Past 2 Years & $.422^{* *}$ \\
\hline Self-Rating of Multicultural Education & $.458^{* *}$ \\
\hline Overall Multicultural Education Score & $.583^{* *}$ \\
\hline$* * p<.01$ &
\end{tabular}

In a similar fashion, eight items from the PDF were combined to measure "multicultural experience" and all items were positively and significantly related to multicultural competence (see Table 5). Multicultural experience items included the number of diversity workshops presented $(r=.441, p<.01)$, and the number of diversity workshops planned $(r=.386, p<.01)$ in the past two years, both of which indicated a positive and significant correlation with multicultural competence. Similarly, there was a significant and positive relationship between the number of research projects that participants engaged in focused on diversity/multiculturalism and their level of multicultural competence $(r=.275, p<.01)$. Of equal significance, were discussions related to diversity had with peers $(r=.465, p<.01)$ and supervisors $(r=$ 
$.424, p<.01$ and $r=.307, p<.01)$. While the length and breadth of these conversations were not indicated or measured, it appears that any discussion, be it formal or informal, indicates a significant correlation with multicultural competence.

While the above correlations suggest a strong relationship between multicultural education and multicultural competence and multicultural experience and multicultural competence, a further examination controlled for potentially confounding demographic variables. To explore these relationships more in depth a hierarchical multiple regression analysis was conducted. The same demographic variables controlled for in the previous analysis were controlled for in these subsequent analyses and produced the same overall variance (19.5\%). The second controlled variable was first multicultural education, then multicultural experiences, and then a final combined analysis of both variables (see Table 6).

Table 5

Pearson Product-Moment Correlations between Multicultural Experience Items and Multicultural Competence

\begin{tabular}{lc} 
Items & $r$ \\
\hline Diversity Workshops Presented in Past 2 Years & $.441^{* *}$ \\
\hline Diversity Workshops Planned in Past 2 Years & $.386^{* *}$ \\
\hline Diversity Research Projects Conducted in Past 2 Years & $.275^{* *}$ \\
\hline Diversity Discussions with Peers/Colleagues & $.465^{* *}$ \\
\hline Formal Diversity Discussions with Supervisor & $.424^{* *}$ \\
\hline Informal Diversity Discussions with Supervisors & $.307^{* *}$ \\
\hline Diversity Feedback from Supervisor & $.218^{* *}$ \\
\hline Self-Rating of Multicultural Experiences & $.519^{* *}$ \\
\hline Overall Multicultural Experience Score & $.622^{* *}$ \\
\hline$* * p<.01$ &
\end{tabular}

Multicultural education demonstrated significant variance above and beyond that accounted for by demographics, $\mathrm{R}_{\text {change }}^{2}=.205, \mathrm{~F}_{\text {change }}(1,152)=51.86, p<.001$, suggesting that an additional $21 \%$ of the variance in multicultural competence scores can be explained or accounted for by multicultural education. Similarly, multicultural experiences accounted for $28 \%$ of the variance above and beyond the controlled for demographic variables, $\mathrm{R}_{\text {change }}^{2}=.287, \mathrm{~F}_{\text {change }}(1,152)=84.45, p<.001$. When both variables were combined and then controlled for, they produced a total variance of $31.1 \%$ above and beyond demographics. Therefore, the overall variance $\left(\mathrm{R}^{2}=.506, \mathrm{~F}(8,151)=47.57, p<.001\right)$ in multicultural 
competence due to demographic variables and multicultural education and experience is $50.6 \%$, suggesting that the combination of pertinent demographics, multicultural education, and multicultural experience is a very strong predictor of multicultural competence.

Table 6

Summary of Hierarchical Regression Analysis for Demographic Variables, Multicultural Experience and Multicultural Education Explaining Variance in Multicultural Competence

\begin{tabular}{lcccc} 
Predictor & $\mathrm{R}^{2}$ & $\begin{array}{c}\mathrm{R}^{2} \\
\text { Change }\end{array}$ & $\mathrm{F}_{\text {Change }}$ & $p$ \\
\hline $\begin{array}{l}\text { Demographic Variable } \\
\quad \text { Gender }\end{array}$ & .195 & .195 & 6.188 & .000 \\
$\quad$ Race & & & & \\
$\quad$ Socially Marginalized Group & & & & \\
$\quad$ Highest Degree & & & & \\
$\quad$ Years in Student Affairs & .400 & .205 & 51.85 & .000 \\
\hline Multicultural Education & .483 & .287 & 84.449 & .000 \\
Multicultural Experience & .506 & .311 & 47.570 & .000 \\
Multicultural Education and Experience & & & & \\
\hline
\end{tabular}

\section{Discussion}

The purpose of this study was to examine multicultural competence among student affairs professionals responsible for leadership development and education on campus. In particular, the study explored the relationship between multicultural competence and specific variables such as racial identity and multicultural education and experiences.

With respect to the relationship between racial identity and multicultural competence, the study demonstrated that both phases of racial identity development strongly correlated with multicultural competence. This finding is consistent with previous research on multicultural competence in student affairs. In their studies of student affairs professionals, Weigand (2005) and Miklitsch (2005) found that racial identity accounted for $45 \%$ and $41 \%$ of the variance in multicultural competence above and beyond demographics respectively. This finding is also consistent with the theoretical perspective. According to Helms (1995a), Phase I represents a less mature racial identity status, therefore it would make sense that participants who had higher Phase I racial identity scores would score lower on multicultural competence. Likewise, Phase II racial identity development represents a more mature racial identity status, substantiating the finding that participants who demonstrated higher Phase II racial identity scores were more likely to have higher multicultural competence scores. Overall, racial identity was a strong predictor of multicultural competence among student affairs professionals responsible for leadership education, above and beyond demographic variables. This finding supports Pope, Reynolds, and Mueller's (2004) assertion that developing multicultural competence involves more than external factors, such as attending cultural events and appearing to be culturally sensitive. Rather, this unique relationship between racial 
identity and multicultural competence suggests a need for student affairs professionals to continue to reflect on experiences and challenge existing worldviews, stereotypes, and assumption.

In addition, the results of this study suggest that multicultural education and experiences may also be a factor in achieving multicultural competence. Overall, multicultural education accounted for $20.5 \%$ of the variance in multicultural competence scores, consistent with similar studies exploring the relationship between multicultural competence and multicultural education. In 2005, Weigand reported a variance of $20 \%$ in MCSA-P2 scores among orientation professionals and Miklitsch (2005) reported a variance of $36.8 \%$ in MCSA-P2 scores among residence life professionals, both after controlling for key demographic variables. Similarly, Mueller and Pope (2001) found multicultural training and education to be significantly correlated with multicultural competence. Also significant was the relationship between multicultural competence and diversity courses taken. Consistent with previous research (Weigand, 2005), those who were required to take one or more diversity courses had significantly higher multicultural competence scores than those who did not take any diversity courses, lending support and evidence for the benefits of requiring graduate students to complete a diversity course as part of the professional preparation.

In a similar fashion, multicultural experience as a factor also correlated with multicultural competence. This finding supports earlier research (Franklin-Craft, 2010; Miklitsch, 2005; Muller \& Pope, 2001; Pope $\&$ Mueller, 2005; Weigand, 2005) demonstrating the significant relationship between multicultural experiences and multicultural competence. While all of the individual items demonstrated significance, in descending order the strongest were participants' self-rating of their level of experience with multicultural issues, frequency of diversity discussions with peers/colleagues, number of diversity workshops presented in the last two years, formal diversity discussions with supervisors, the number of diversity workshops planned in the last two years, informal diversity discussions with supervisor, diversity research projects conducted in the past two years, and the frequency of feedback from their supervisor on their ability to work with diverse students and colleagues. Of significance to note, professionals who had formal conversations with supervisors regarding diversity issues and multiculturalism had slightly higher, though non-significant, multicultural competence scores than those who had more informal discussions. This may reflect a level of intentionality on the part of the supervisor or supervisee that indicates a heightened sense of multicultural awareness and a need for these types of conversations.

The results indicated that together, the multicultural education and experiences accounted for over half of the variance in multicultural competence scores above and beyond that accounted for by the demographics. Thus, the combination of multicultural education and experience is by far a stronger predictor of multicultural competence than either construct on its own, as supported by previous studies (Miklitsch, 2005; Weigand, 2005). These findings provide strong evidence for student affairs professional responsible for leadership education to continue to find ways and invest time in purposeful educational and experiential activities focused on multicultural or diversity issues, as a way of personally enhancing their own multicultural competence. 


\section{Implications for Practice}

Very little literature exists surrounding the role of the leadership educator, particularly as it relates to their ability to create meaningful and high impact programs and activities for students. Data from the MultiInstitutional Study of Leadership (Dugan \& Komives, 2007) suggested the strongest predictor of student learning (across specific learning outcomes) was the opportunity to engage in cross-cultural conversations. This finding is reason for leadership educators to pause and reflect on their own multicultural awareness, knowledge, and skill, or rather multicultural competence, and how this translates into practice.

Specifically, leadership educators may have a unique opportunity to not only develop their own racial identity, but through conscious program development and implementation, may have the opportunity to significantly impact the racial identity development of their staff and students. For example, conversations about what is leadership and who is a leader can challenge existing assumptions and worldviews about the typical leader, which often translates into a physical picture of someone in a dominant group (i.e., white male). More specifically, the opportunities that leadership educators create to engage students in conversations about differences can challenge White students to further develop their racial identity through reflection on their own experiences, potentially causing them to question previously held erroneous beliefs. This opportunity presents a new challenge for leadership educators in not only being comfortable in facilitating these dynamic conversations, but more importantly the challenge to have some level of competence in facilitating these conversations.

In addition to self-reflection, professional development must be an ongoing and intentional process for every student affairs professional (Miklitsch, 2005; Mueller, 1999; Mueller \& Pope, 2001; 2003). Education and experiences such as attending workshops focused on diversity or reading articles, books, or research focused on diversity may enhance multicultural competence and improve the effectiveness of professionals in meeting the needs of a diverse student body. For leadership educators in particular, this may mean attending workshops on campus that speak to the diversity of the student body (i.e., working with international students, supporting lesbian, gay, bisexual, transgender [LGBT] students, or programming for students with disabilities) to enhance the understanding of the student population that may be participating in campus leadership programs. By taking responsibility for educating oneself about different cultures and therefore different approaches to leadership, professionals can provide more meaningful and high impact programs for a diverse student body. Leadership educators who are looking to infuse multicultural issues into their leadership programs must first have awareness and understanding of what diversity is and how it relates to the students they are serving (Ostick, 2006). This concept of educating the educator cannot be overstated, and those student affairs professionals who are able to recognize the different approaches that others bring to the discussion of leadership will be more effective in facilitating meaningful dialogue (Edwards, 2006), which is not only important at the student level, but also has significant potential at the professional level.

Student affairs professionals responsible for leadership education can enhance their multicultural competence and their effectiveness as leadership educators, by taking diversity courses, attending workshops, reading books or articles, and engaging in dialogues with peers and supervisors. As a 
profession, leadership educators are becoming acutely aware of the need for a new approach to the study and practice of leadership, particularly a cultural approach (Edwards, 2006).

\section{Limitations, Future Research, and Conclusions}

This study has several significant limitations. First, the sample for this study was not randomly selected, but rather targeted through two national organization listservs specific to leadership education, limiting the ability to generalize the results to all leadership educators or all student affairs professionals, as membership in these organizations is voluntary and only represent a portion of the student affairs population responsible for leadership education.

In a similar capacity, when using this particular sampling method, there is no way to control for the types of professionals who respond. For example, someone who may have split responsibility in functional areas such as leadership and residence life may have chosen to not participate based on an assumption that the study was only seeking professionals solely responsible for leadership education. Similarly, the breadth of the sample, which allowed for varying levels of responsibility for leadership education, may limit the ability to generalize results for leadership educators as a specific population.

Finally, all of the instruments used in this study are self-report measures and therefore may be subject to response bias, particularly when it comes to evaluating one's own level of multicultural competence.

Precautions were taken to limit the effects of response bias, including the omission of labeled measures of racial identity and multicultural competence as well as the use of an online survey. Previous research has indicated that respondents answer online surveys with greater self-disclosure or that there is no difference at all in responses when compared with pencil and paper surveys (Buchanan as cited in Buchanan, 2002; Knapp \& Kirk, 2003).

\section{Conclusion}

In conclusion, the results of this study demonstrate the significance of racial identity and multicultural education and experiences in relation to multicultural competence among leadership educators. While this study adds to a small, but growing body of research in this area, more is needed to understand the unique differences and the impact of measures not considered in this particular study, such as multicultural experiences and education outside the realm of student affairs (i.e. family influences, living or studying outside the country). Additionally, with respect to leadership educators, more research is needed to understand other variables of interest with respect to those professionals who wear numerous hats in other functional areas, and how those roles may influence multicultural competence. The increasingly dynamic nature of our student population calls for dynamic professionals who are effectively capable of understanding, interacting, and working with diverse students. Specifically, student affairs professionals responsible for leadership education are in a unique position to facilitate and foster a campus environment that is inclusive and affirming. Therefore, it is imperative that leadership educators adopt multicultural competence as an essential competency within their profession, continue to seek out opportunities to further enhance personal multicultural competence, and infuse it into daily practice. 


\section{References}

American College Personnel Association [ACPA] (1996). Principles of good practice for student affairs.

American College Personnel Association [ACPA] (2010). Joint task force on professional competencies.

Astin, A. W., \& Astin, H. S. (2000). Leadership reconsidered: Engaging higher education in social change. Battle Creek, MI: W. K. Kellogg Foundation.

Barr, M. J., \& Desler, M. K. (Eds.) (2000). The handbook for student affairs administration (2 ${ }^{\text {nd }}$ ed.). San Francisco: Jossey-Bass.

Buchanan, T. (2002). Online assessment: Desirable or dangerous? Explorations to inform professional practice. Professional Psychology: Research.

Burns, J. M. (1978). Leadership. New York: Harper \& Row.

Colby, A., Ehrlich, R., Beaumont, E., \& Stephens, J. (2003). Educating undergraduates for responsible citizenship. Change, 35(6), 40-48.

Council for the Advancement of Standards in Higher Education (2006). CAS professional standards for higher education ( $6^{\text {th }}$ ed.). Washington, DC: Author.

Cross, W. E. (1971). The Negro-to Black conversion experience: Towards a psychology of Black liberation. Black World, 20(9), 13-27.

Dugan, J. P., Komives, S. R., \& Segar, T. C. (2008). College student capacity for socially responsible leadership: Understanding norms and influences of race, gender, and sexual orientation. NASPA Journal, 45(4), 475-500.

Edwards, K. E. (2006). Bringing leadership into focus: Approaches, lenses, and models. In S. R. Komives, J. Dugan, J. Owen, C. Slack, \& W. Wagner (Eds.), Handbook for Leadership Programs. College Park, MD: National Clearinghouse for Leadership Programs.

Evans, N. J., Forney, D. S., \& Guido-DiBrito, F. (2010). Student development in college: Theory, research, and practice. San Francisco: Jossey-Bass.

Franklin-Craft, A. (2010). An assessment of the intercultural competence of student affairs 
administrators (Ed.D. dissertation). Retrieved from ProQuest Dissertations \& Theses database (UMI No. 3435119)

Flowers, L. A. (2003). National study of diversity requirements in student affairs graduate programs. NASPA Journal, 40, 72-82.

Higher Education Research Institute (1996). A Social Change Model of Leadership Development: Guidebook version III. College Park, MD: National Clearinghouse for Leadership Programs.

Dugan, J. P., \& Komives, S. R. (2007). Developing leadership capacity in college students: Findings from a national study. A report from the Multi-Institutional Study of Leadership. College Park, MD: National Clearinghouse for Leadership Programs.

Helms, J. E. (1984). Toward a theoretical explanation of the effects of race on counseling: A black and white model. The Counseling Psychologist, 12(3-4), 153-165.

Helms, J. E. (1990a). Introduction: Review of racial identity terminology. In J. E. Helms (Ed.), Black and White Racial Identity: Theory, Research, and Practice, 3-8. Westport, CT: Praeger.

Helms, J. E. (1990c). An overview of Black racial identity theory. In J. E. Helms (Ed.), Black and White racial identity: Theory, research, and practice, 9-32. Westport, CT: Praeger.

Helms, J. E. (1990d). Toward a model of White racial identity development. In J. E. Helms (Ed.), Black and White racial identity: Theory, research, and practice, 49-66. Westport, CT: Praeger.

Helms, J. E. (1995a). An update of Helms' White and People of Color racial identity models. In J. G. Ponterotto, J. M. Casas, L. A. Suzuki, \& C. M. Alexander (Eds.), Handbook of Multicultural Counseling, 181-198. Thousand Oaks, CA: Sage.

Helms, J. E. (1995b). Preliminary scoring key for the People of Color (POC) Racial Identity Attitude Scale. Unpublished manuscript. 
Helms, J. E. (1996). Toward a methodology for measuring and assessing racial identity as distinguished from ethnic identity. In G. R. Sodowsky, \& J. C. Impara (Eds.). Multicultural Assessment in Counseling and Clinical Psychology, 143-192. Lincoln, NE: Burros Institute of Mental Measurement.

Helms, J. E., \& Carter, R. T. (1990). Development of the White racial identity inventory. In J. E. Helms (Ed.), Black and White racial identity: Theory, research and practice, 67-80. Westport, CT: Greenwood.

Helms, J. E., \& Carter, R. T. (2002). Preliminary scoring information for the WRIAS social attitudes inventory (revised). Unpublished memo.

Jacoby, B.C., \& Associates (1996). Service-learning in higher education: Concepts and practices. San Francisco: Jossey-Bass.

King, P. M., \& Howard-Hamilton, M. (2003). An assessment of multicultural competence. NASPA Journal,40, 119-133.

Knapp, H., \& Kirk, S. A. (2003). Using pencil and paper, internet and touch-tone phones for selfadministered surveys: Does methodology matter? Computers in Human Behavior, 19, 117-134.

Komives, S. R., Dugan, J. P., Owen, J. E., Slack, C., Wagner, W., \& Associates (2011). Handbook for Student Leadership Programs (2 ${ }^{\text {nd }}$ ed.). National Clearinghouse of Leadership Programs.

Komives, S. R., Lucas, N., \& McMahon, T. R. (2007). Exploring leadership: For college Students who want to make a difference. San Francisco: Jossey-Bass.

Martin, S. C. (2005). A pragmatic exploration of the multicultural competence of community college student affairs practitioners. (Doctoral dissertation). Retrieved from ProQuest Dissertations \& Theses database. (UMI No. 3156013)

Mastrodicasa, J. M. (2004). The impact of diversity courses in student affairs graduate programs on multicultural competence of student affairs professionals. (Doctoral Dissertation). 
Retrieved from ProQuest Dissertations \& Theses database. (UMI No. 3135202)

McEwen, M. K., \& Roper, L. D. (1994). Interracial experiences, knowledge, and skills of master's degree students in graduate programs in student affairs. The Journal of College Student Development, 35, 81-87.

Miklitsch, T. (2005). The relationship between multicultural education, multicultural experiences, racial identity, and multicultural competence among student affairs professionals. (Doctoral Dissertation). Retrieved from ProQuest Dissertations \& These database. (UMI No. 3185290)

Miller, T. K. (Ed) (2003). The book of professional standards for higher education: 2003. Washington, DC: Council for the Advancement of Standards in Higher Education.

Mueller, J. A. (1999). The relationship between White racial consciousness and multicultural competence among White student affairs practitioners. (Doctoral Dissertation). Retrieved from ProQuest Dissertations \& Theses database. (UMI No. 9950060)

Mueller, J. A., \& Pope, R. L. (2001). The relationship between multicultural competence and White racial consciousness among student affairs practitioners. Journal of College Student Development, 42, 133-144.

Mueller, J. A., \& Pope, R. L. (2003). The relationship of demographic and experience variables to White racial consciousness among student affairs practitioners. NASPA Journal, 40, $149-171$.

Northouse, P. G. (2007). Leadership theory and practice ( $4^{\text {th }}$ ed.). Thousand Oaks, CA: Sage.

Ostick, D. (2006). Leadership and diversity. In S. R. Komives, J. Dugan, J. Owen, C. Slack, \& W. Wagner (Eds.), Handbook for Leadership Programs. College Park, MD: National Clearinghouse for Leadership Programs.

Ottavi, T. M., Pope-Davis, D. B., \& Dings, J. G. (1994). The relationship between white racial identity attitudes and self-reported multicultural counseling competences. Journal of Counseling Psychology, 41, 149-153. 
Pope, R. L., \& Reynolds, A. L. (1997). Student affairs core competencies: Integrating multicultural awareness, knowledge, and skills. Journal of College Student Development, $38,266-277$.

Pope, R. L., Reynolds, A. L., \& Muller, J. A. (2004). Multicultural competence in student affairs. San Francisco: Jossey-Bass.

Pope, R. L., \& Mueller, J. A. (2000). Development and initial validation of the Multicultural Competence in Student Affairs-Preliminary 2 (MCSA-P2) scale. Journal of College Student Development, 41(6), 599-608.

Pope, R. L., \& Mueller, J. A. (2005). Faculty and curriculum: Examining multicultural competence and inclusion. Journal of College Student Development, 46(6), 679-688.

Rost, J. (1991). Leadership for the twenty-first century. New York: Praeger.

Scott, D. (2004, September 27). Are campus leadership programs developing the leaders society needs? Netresults.

Talbot, D. (1992). A multi method study of the diversity emphasis in master's degree programs In college student affairs. (Doctoral dissertation). Retrieved from Digital Dissertations $(532198 \mathrm{~A})$

Wagner, W. (2006). Competencies of leadership educators. In Komives, S. R., Dugan, J. P., Owen, J., Slack, C., \& Wagner, W. (Eds.), Handbook for Student Leadership Programs. College Park, MD: NCLP.

Weigand, M. J. (2005). The relationships between multicultural competence, racial identity, and multicultural education and experiences among students affairs professionals responsible for first-year student orientation programs. (Doctoral dissertation). Retrieved from Digital Dissertations (3169117) 


\section{Author Biography}

Dr. Amy Wilson is an assistant professor in the Higher Education and Student Affairs Administration program at Buffalo State in Buffalo, New York. She was previously an administrator in student affairs for 12 plus years, serving most recently as the Director of the Center for Student Leadership and Community Engagement at the University at Buffalo. Dr. Wilson earned her doctorate in Higher Education Administration from the University at Buffalo and her master's in College Student Personnel from Western Illinois University. 